\title{
SPOŁECZNA PRZESTRZEŃ INTERNETU JAKO MIEJSCE PRACY ZAWODOWEJ
}

\section{Abstract \\ The social space of the Internet as a place of work}

Technological progress and the development of the Internet network have changed the way and type of work. Not only the form of the work performed changed, but also its scope and role. The Internet has become a place of professional work of modern man. In the context of these changes, we must answer of two important questions. First: in what area of the Internet human work is of the greatest importance? Second: what benefits and losses brings work done on the Internet? The whole article is of an illustrative nature and constitutes an introduction to further considerations on the impact of professional work on the Internet network.

Keywords: Internet, professional work and activity, telework

\section{Streszczenie}

Postęp technologiczny, z rozwojem sieci internetowej na czele, znacznie wpłynął na sposób i rodzaj wykonywanej pracy zawodowej. Nie tylko forma i rytm wykonywanej pracy uległy zmianom, wytworzone zostały także obszary w ramach Społecznej Przestrzeni Internetu, w których pracownicy, wykorzystując dostępne zasoby, wykonują czynności ogólnozawodowe. W niniejszym artykule postawiono dwa kluczowe pytania. Pierwsze z nich brzmi: W jakim obszarze społecznej przestrzeni Internetu praca i aktywność zawodowa jednostki mają największe znaczenie? Zaś drugie odnosi się do korzyści i strat wynikających z wykorzystania sieci WWW do realizacji czynności i zadań zawodowych. Całość artykułu ma charakter poglądowy i stanowi wprowadzenie do dalszych rozważań nad wpływem zakotwiczenia pracy zawodowej w sieci internetowej.

Słowa kluczowe: Internet, praca i aktywność zawodowa, telepraca 


\section{Wstęp}

Kilkanaście lat temu w naszym kraju dostrzeżono nowe możliwości, które daje sieć internetowa. Zapanował zachwyt nad wielością funkcji narzędzi mobilnych i w wieloraki sposób wpłynął na postrzeganie pracy zawodowej oraz jej funkcji. Zaczęto dostrzegać alternatywne drogi rozwoju zawodowego, budowania marki osobistej czy edukacji zawodowej w niemal każdej branży. Internet otwierając przed pracodawcami i pracownikami nowe możliwości działań, był kreowany na jedno z podstawowych narzędzi poprawiania wydajności i jakości pracy.

Obecnie nastał czas świadomego, kreatywnego i efektywnego wykorzystania wspomnianego medium do czynności wspomagających szeroko pojętą aktywność zawodową Polaków. Jak wskazują wyniki badań z 2017 roku, z Internetu przynajmniej raz w tygodniu korzystają w Polsce dwie trzecie dorosłych $(67 \%)^{3}$, przy czym jego wykorzystanie sprzyja aktywności zawodowej [Felisiak, 2017]. Dzieje się tak dlatego, że sieć internetowa wpływa na modernizację organizacji systemu pracy. Elastyczne i nowe formy zatrudnienia w znaczny sposób rozwinęły się właśnie dzięki możliwościom, jakie daje Internet.

Warto zastanowić się, w jaki sposób społeczna przestrzeń Internetu staje się miejscem pracy zawodowej oraz w jakim zakresie sieć może mieć wpływ na rozwój zawodowy pracowników.

\section{Praca w obszarze społecznej przestrzeni Internetu}

Termin „praca zawodowa” możemy zaliczyć do grupy pojęć wieloznacznych, stanowiących przedmiot zainteresowań wielu dyscyplin naukowych. W rozważaniach psychologicznych praca to „system czynności wyróżnionych i ukierunkowanych na przekształcenie otoczenia, wykonywanych względnie stale, gdy jej wykonawca ma odpowiednie kwalifikacje formalne" [Szewczuk, 1998: 654]. W literaturze pedagogicznej pracę definiuje się jako świadome działanie człowieka mające na celu zaspokojenie indywidualnych potrzeb przez tworzenie dóbr, poprzez podejmowany przez pracującego trud, fizyczny lub umysłowy [Pilch, 2003: 781]. W socjologii praca jednostki jest interpretowana jako świadoma działalność charakteryzująca się pokonywaniem trudności, której celem jest zaspokajanie określonych potrzeb człowieka [Marciszewski, 1983: 35]. Zaś z punktu widzenia ekonomii praca stanowi szczególny rodzaj towaru, jaki człowiek sprzedaje na rynku pracy w postaci swoich możliwości fizycznych i intelektualnych, kwalifikacji i umiejętności w celu produkowania dóbr i usług [Kamerschen i in., 1992: 670].

3 Badanie „Aktualne problemy i wydarzenia” (323) przeprowadzono metodą wywiadów bezpośrednich (face-to-face) wspomaganych komputerowo (CAPI) w dniach 30 marca-6 kwietnia 2017 r. na liczącej 1075 osób reprezentatywnej próbie losowej dorosłych mieszkańców Polski. 


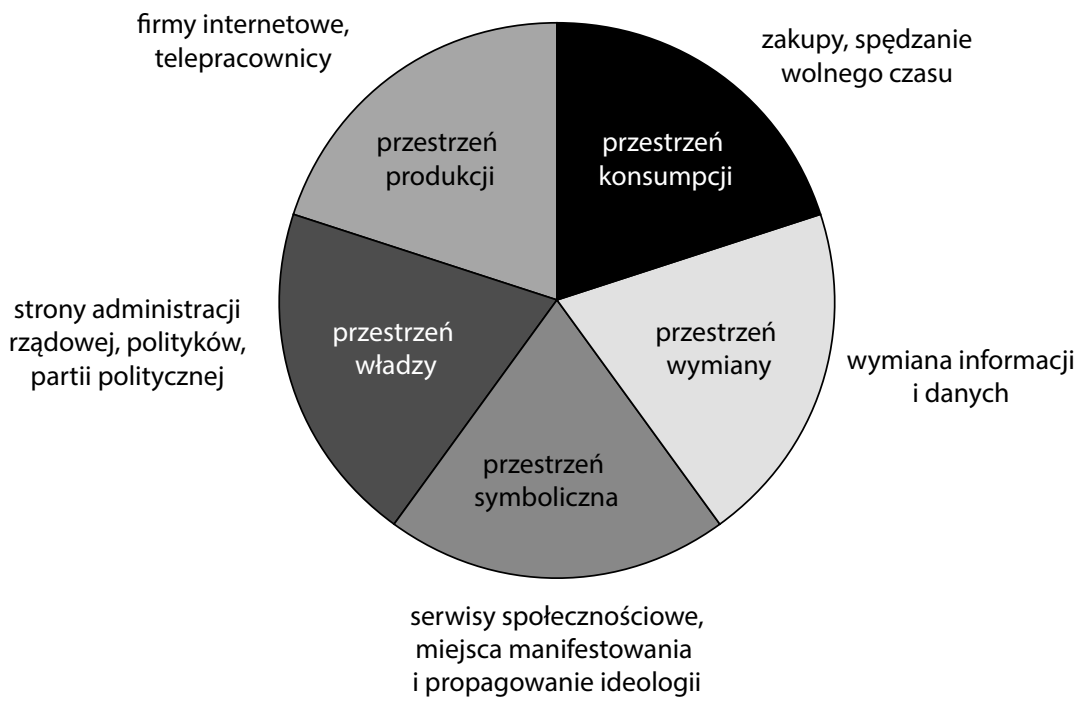

Schemat 1. Typologia społecznej przestrzeni Internetu

Źródło: Szpunar, 2008: 227.

Możemy zatem przyjąć za Edwardem Marciszewskim [1983: 6], że praca jako kategoria społeczna, w skład której wchodzą umiejętności pracy, sposoby jej organizowania, narzędzia, urządzenia techniczne oraz wyprodukowane dobra, stanowi element kultury danego społeczeństwa. Zasadne wydaje się więc zastanowienie, gdzie w obrębie społecznej przestrzeni Internetu usytuowana jest praca zawodowa człowieka.

Społeczna przestrzeń Internetu stanowi pewien specyficzny wycinek rzeczywistości społecznej, której przyswajanie dokonuje się przez czynności zapośredniczone, takie jak: tworzenie domowych stron WWW, prowadzenie blogów, wgrywanie do sieci własnych zdjęć czy zamieszczanie przemyśleń [Szpunar, 2008: 226]. Tego typu działania podejmuje niemal każdy uczestnik sieci, dlatego też przestrzeń Internetu jest tworzona przez wszystkich aktywnych jego użytkowników.

Wizja przestrzeni Internetu, w której ,zanurzony” jest współczesny pracujący człowiek, wydaje się szczególnie interesująca głównie ze względu na wnikliwą charakterystykę poszczególnych perspektyw analitycznych (zob. schemat 1).

Pierwsza i najpopularniejsza przestrzeń Internetu to obs zar w y miany. Wiąże się on z podstawową funkcją sieci, czyli z narzędziem służącym do poszukiwania informacji i obrotu nimi. W tej przestrzeni jednostki mogą służyć sobie radą i pomocą lub wzajemnie się dyskredytować, zamieszczając również informacje nieprawdziwe czy obraźliwe. P r z e s tr ze ń w ła d z y jest obszarem aktywności administracji rządowej, poszczególnych polityków czy partii politycznych, którzy Internet wykorzystują jako doskonałe miejsce promocji siebie i kontaktu z potencjalnymi wyborcami. Przestrzeń symboliczna jest to obszar, 
w którym tworzone są w dużej mierze serwisy społecznościowe. Jest to przestrzeń kształtowania się systemów wartości i reguł uznawanych w sieci. P r ze s tr zeń k o n s u p c ji to obszar, w którym jednostki mają możliwość zagospodarowywania swojego czasu wolnego i dokonywania różnego rodzaju transakcji [Szpunar, 2008: 226-228].

Najistotniejszą przestrzenią wykreowaną w ramach społecznej przestrzeni Internetu, przestrzenią, która ma bezpośredni wpływ na sposób wykonywania pracy zawodowej przez jednostkę, jest przestrzeń produkcji. W przestrzen i pro$\mathrm{d} \mathrm{u} \mathrm{k} \mathrm{c} \mathrm{j} \mathrm{i} \mathrm{działają} \mathrm{firmy} \mathrm{internetowe,} \mathrm{a} \mathrm{zatrudnienie} \mathrm{znajduje} \mathrm{wielu} \mathrm{telepracowni-}$ ków, dla których Internet jest głównym źródłem utrzymania [Szpunar, 2008: 228]. Jest to obszar ekonomiczno-społecznego działania jednostek, sfera kształtowania się nowych zawodów i specjalizacji związanych z siecią, jak i miejsce marketingu oraz promocji dóbr i usług.

Przestrzeń produkcji może mieć również wymiar indywidualny, przejawia się on m.in. w twórczości artystycznej czy wynalazczości, którą użytkownicy dzielą się z innymi poprzez portale i serwisy do tego przeznaczone (np.: Myspace, YouTube) lub portale społecznościowe (Facebook, Instagram, Snapchat, Twitter itp).

Warto nadmienić, że wymienione przestrzenie nie występują odrębnie, lecz nakładają się na siebie, tworząc społeczną architekturę sieci. Nie da się bowiem oddzielić pewnych właściwości i skutków zastosowania przestrzeni internetowej w kontekście pracy zawodowej. Rozdział tych przestrzeni i analizowanie danego obszaru sieci pod kątem każdej z nich pozbawiłyby nas informacji związanych z motywami powstania czy spełnianymi przez dany obszar funkcjami, dlatego pisząc o usytuowania pracy w społecznej przestrzeni Internetu, musimy brać pod uwagę wszystkie wymiary aktywności jednostki w sieci, ze szczególnym uwzględnieniem przestrzeni produkcji.

\section{Geneza, definicja i rodzaje telepracy}

Praca wykonywana w wirtualnej przestrzeni produkcji nazywana jest również w literaturze przedmiotu e-pracą lub telepracą. Za jej prekursora uważa się Jacka M. Nillesa, a jej genezę wiąże się przede wszystkim z wielkim kryzysem paliwowym, który wybuchł w Stanach Zjednoczonych na przełomie lat sześćdziesiątych i siedemdziesiątych XX wieku. Miał on wpłynąc znacząco na transport pracowników do miejsc pracy, a w konsekwencji wymusić ich mniejszą mobilność przestrzenną i tym samym zrewolucjonizować rynek pracy zdalnej [Duchna, Paluszkiewicz, 2013: 154-156]. Pojawienie się e-pracy było również wynikiem wprowadzenia nowych form telekomunikacji i skomputeryzowania wielu dziedzin życia, które w konsekwencji zdominowały też sferę zawodowej aktywności człowieka [Książek, 2004: 13].

Sam termin „telepraca” jest różnie definiowany. Według Nillesa jest to każdy rodzaj zastępowania podróży związanych z pracą techniką informacyjną. To przemieszczenie pracy do pracowników zamiast pracowników do pracy [Nilles, 
2003: 8-11]. Telepracę definiuje się również jako „formę organizacji i wykonywania pracy przy użyciu technologii informacyjnej, w związku z umową o pracę lub stosunkiem pracy" [Zakrzewska-Szczepańska, 2005: 34]. W takiej formie praca może być świadczona zarówno w siedzibie pracodawcy, jak i poza siedzibą podmiotu zatrudniającego. Wynika $z$ tego, że telepraca jako forma organizacji pracy polega na świadczeniu przez pracownika pracy na rzecz pracodawcy z dala od tradycyjnie pojmowanego miejsca pracy, tj. zakładu pracy, a przekazywanie jej wyników odbywa się za pomocą urządzeń teleinformatycznych [Zakrzewska-Szczepańska, 2005: 34].

W zależności od charakteru i miejsca pracy możemy wyróżnić następujące rodzaje telepracy [Makowiec, 2016: 17-18]:

- telepraca domowa (tele-homeworking) - pracownik świadczy pracę w domu zamiast dojeżdżać do siedziby przedsiębiorstwa;

- telepraca naprzemienna (homebased teleworking) - pracownicy wykonują większość pracy poza siedzibą pracodawcy, najczęściej w domu, np. pracują cztery dni w domu, a jeden w biurze;

- telepraca mobilna (nomadic teleworking) - dotyczy np. pracowników działów sprzedaży, inżynierów eksploatacyjnych czy przedstawicieli ubezpieczeniowych. Pracownicy ci są zatrudnieni w tradycyjny sposób, ale ze względu na charakter pracy pozostają $\mathrm{w}$ kontakcie $\mathrm{z}$ firmą za pomocą telefonu komórkowego, smartfonu, tabletu czy laptopa, bez konieczności świadczenia pracy w biurze. Większość czasu pracują u klientów, w domu lub w drodze. Praca może być wykonywana również w samochodzie, pociągu, samolocie czy hotelu;

- telepraca doraźna (ad hoc teleworking) - dotyczy pracowników świadczących pracę w biurze firmy, którzy w wyjątkowych, sporadycznych, dokładnie określonych przypadkach, mogą wykonywać pracę $\mathrm{w}$ domu;

- telewioski, telecentra, e-centra pracy, centra coworkingowe - pracownicy świadczą pracę $\mathrm{w}$ ośrodkach wyposażonych w urządzenia umożliwiające realizowanie zadań za pośrednictwem narzędzi teleinformatycznych. Ośrodki pełnią jednocześnie funkcje wirtualnych biur, umożliwiających pracę osobom, które nie mają możliwości technicznych lub też nie chcą wykonywać powierzonej im pracy w domu, natomiast dojazd do siedziby macierzystego przedsiębiorstwa jest dla nich zbyt kłopotliwy, czasochłonny i kosztowny;

- telepraca zamorska - pracownicy świadczą pracę w różnych krajach i na różnych kontynentach, co umożliwia np. dwudziestoczterogodzinną pracę nad projektem.

Przeniesienie aktywności zawodowej człowieka i systemu pracy do społecznej przestrzeni Internetu niesie za sobą nie tylko szereg korzyści, lecz także wiele problemów związanych ze zmianą postrzegania zarówno samej pracy, jak i roli pracodawcy i pracownika. Warto się więc zastanowić, o jakich konsekwencjach takiego stanu rzeczy należy pamiętać. 


\section{Bilans korzyści i strat wynikających z przeniesienia czynności zawodowych do sieci internetowej}

Jeszcze kilka lat temu możliwości, które dawała sieć internetowa pracownikom, ograniczone były do kilku obszarów zawodowych związanych z technologiami informatycznymi. O ile pracę przy użyciu sieci mogli wykonywać informatycy, programiści czy osoby zarządzające systemami informatycznymi, o tyle współcześnie przedstawiciele niemal każdego zawodu, łącznie z zawodami bezpośredniego kontaktu (lekarze, nauczyciele czy pracownicy służb administracyjnych), mogą wykonywać swoją pracę, wykorzystując do tego społeczną przestrzeń Internetu.

Wykonywanie pracy zawodowej przy użyciu sieci niesie za sobą istotną korzyść w postaci dużej swobody działania w zakresie organizacji pracy. Jak możemy wyczytać z raportów Eurofound, w krajach europejskich w 2017 roku zaledwie $17 \%$ zatrudnionych stanowili telepracownicy. W niektórych krajach liczba telepracowników utrzymuje się na poziomie niemal 40\% (Dania i Szwecja), zaś w innych stanowi zaledwie $10 \%$ (Włochy) ${ }^{4}$.

Warto podkreślić, że wykonywanie czynności zawodowych przy użyciu Internetu częściej spotykana jest w niektórych zawodach i zwykle kojarzy się z wysoko wykwalifikowaną pracą umysłową. W Europie 7\% telepracy wykonują menedżerowie, zaś $13 \%$ profesjonaliści lub technicy - np. statystycy lub brokerzy finansowi. Sektory, w których dominuje telepraca, związane są przede wszystkim z edukacją (12\%), usługami finansowymi (8\%) oraz administracją publiczną (3\%) [Tavares, 2017: 30-31].

Nieodzowny element przenoszenia części zadań zawodowych do internetowej przestrzeni produkcji wiąże się z ciągłą edukacją pracowników, i w zakresie samej pracy, i w wymiarze wykorzystywania mobilnych urządzeń czy narzędzi technicznych. Związane z tym trudności i pojawiające się bariery są interpretowane jako negatywny czynnik przenoszenia czynności zawodowych do sieci. Jak słusznie zauważa Grażyna Spytek-Bandurska, praca zakotwiczona w społecznej przestrzeni Internetu cieszy się dużą popularnością w ramach umów cywilnych, które dają stronom wiele niezależności, ale nie zapewniają przywilejów pracowniczych [Spytek-Bandurska, 2013: 144-145].

Jak słusznie zauważa Nilles, w każdej jednostce, w której człowiek wykonuje czynności zawodowe związane z pracą, a której funkcjonowanie podlega mechanizmom ekonomicznym, korzyści wynikające z wysiłków muszą przekraczać poniesione przy nich koszty. I nie ma znaczenia, czy mamy na myśli rodzinę jako instytucję, czy ponadnarodową korporację [Nilles, 2003: 164-165]. Analiza szans i barier w kontekście wykonywania pracy jest więc kluczowym elementem zrozumienia jej zasadności i efektywności, zarówno gdy jest ona wykonywana off-line, jak i on-line.

4 Stan na dzień 28.10.2018. Za: Eurofound, 2017. 
To, co wyróżnia pracę wykonywaną w przestrzeni internetowej od jej tradycyjnej formy, to przede wszystkim [Malcolm, Morgen, 2005: 72-76]:

- ukierunkowanie na funkcje związane z podziałem zadań, gdzie pracownicy wykonują prace o charakterze projektowym;

- charakter menedżerski czynności zawodowych, gdy pracownik staje się własnym kierownikiem i samodzielnie koordynuje wykonywaną pracę;

- zindywidualizowany styl pracy, który dostosowywany jest do poszczególnych zadań zawodowych, przy uwzględnieniu samodzielnego kształtowania przez pracownika czasu przeznaczonego na pracę;

- koncentracja na rezultatach, gdzie praca jest zorientowana na cele stawiane przez pracownika, a nie na zadania, które ma on w danej chwili wykonać;

- mniejsza potrzeba kontroli i nadzoru nad pracownikiem, wynikająca z indywidualnej motywacji do pracy.

Wspomniane cechy pracy wykonywanej w przestrzeni internetowej mają istotny wpływ nie tylko na pracowników, lecz także na pracodawców. Ów wpływ możemy interpretować z punktu widzenia korzyści i strat, które niesie ze sobą przeniesienie czynności zawodowych jednostki do sieciowej przestrzeni produkcji.

Dla pracodawców jedną z najistotniejszych korzyści będzie zmniejszenie kosztów utrzymania pracownika poprzez ograniczenie wydatków np. na koszty dojazdów pracowników do pracy czy tworzenie dla nich przestrzeni pracy (zob. schemat 2).

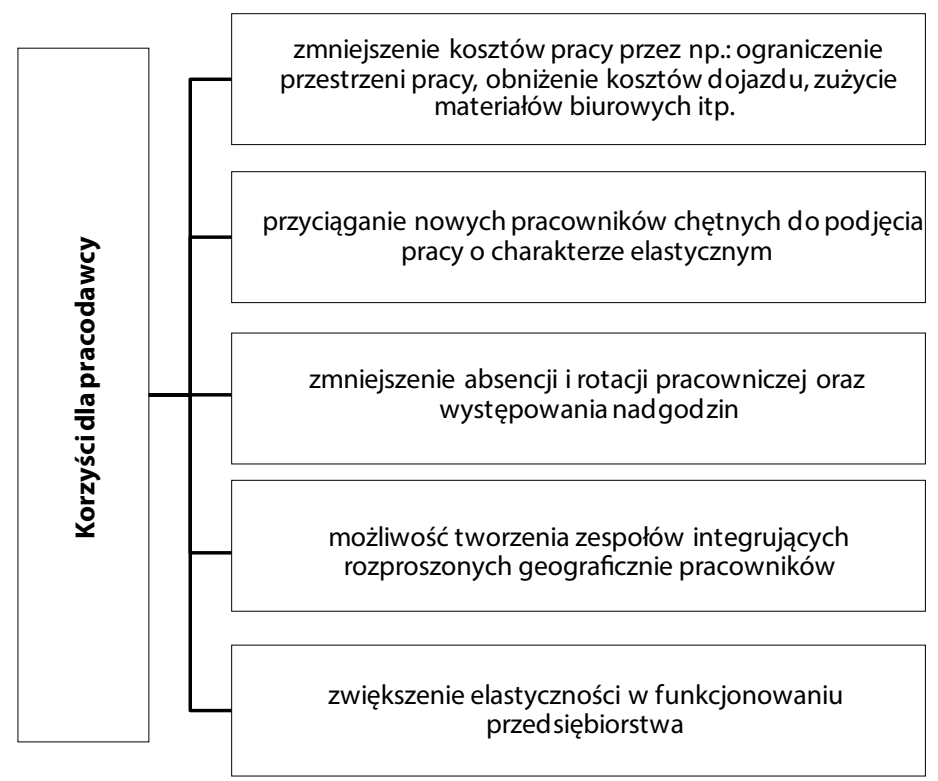

Schemat 2. Korzyści dla pracodawcy wynikające z przeniesienia czynności zawodowych pracownika do społecznej przestrzeni Internetu

Źródło: opracowanie własne na podstawie: Makowiec, 2016: 63. 
Ponadto pracodawca oferujący pracownikom możliwość pracy przy użyciu Internetu wskazuje większą elastyczność miejsca zatrudnienia, co z kolei wpływa na motywację pracowników. Dzięki wykorzystaniu telepracy zauważalna jest również zmniejszona absencja i rotacja pracownicza oraz rzadziej pojawia się problem nadgodzin $\mathrm{w}$ pracy.

Jednak umożliwianie tego typu pracy ma również swoje minusy.

Do znaczących dla pracodawcy minusów wynikających z telepracy zatrudnionych przez niego pracowników należy wyraźne ograniczenie bezpośrednich kontaktów z pracownikami. Brak możliwości bezpośredniej komunikacji i występowanie szumów komunikacyjnych mogą wprowadzać w systemie pracy nieporozumienia, których w przypadku bezpośredniego obcowania ze współpracownikiem można byłoby łatwo uniknąć (zob. schemat 3).

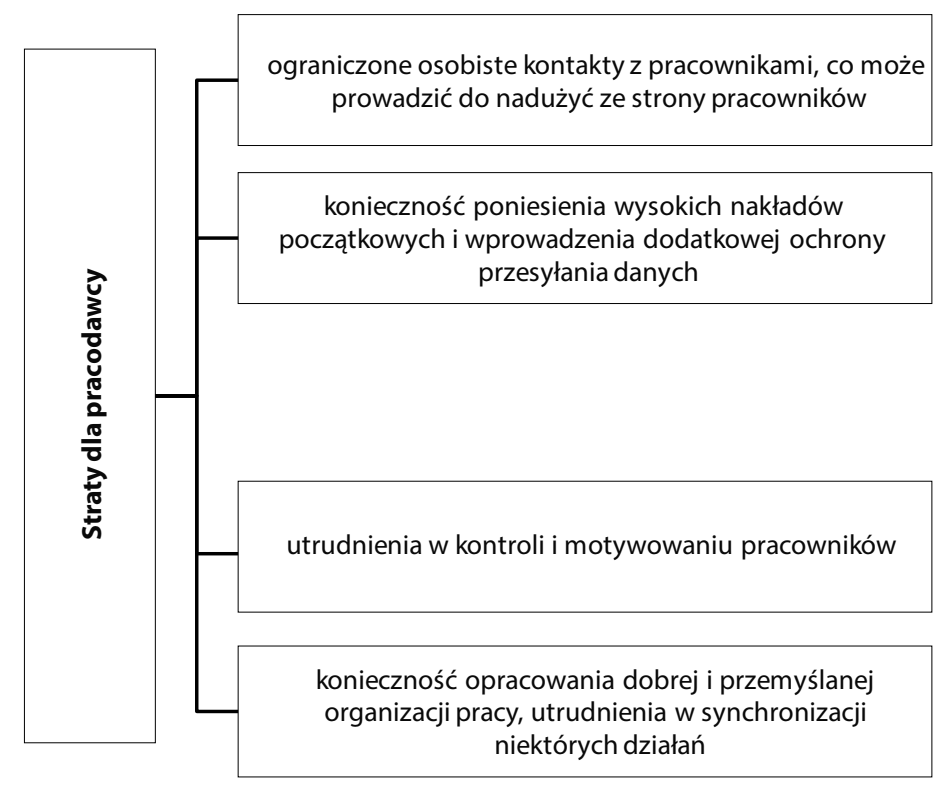

Schemat 3. Straty, które ponosi pracodawca, wynikające z przeniesienia czynności zawodowych pracownika do społecznej przestrzeni Internetu Źródło: opracowanie własne na podstawie: Makowiec, 2016: 63.

Nie tylko pracodawca może ponieść straty z tytułu wykorzystania sieci internetowej do wykonywania czynności zawodowych. Pracownik jako podmiot wykonujący zadania zawodowe również może je ponosić (zob. schemat 4). Dodatkowo zatrudnieni telepracownicy mają prawo do rekompensaty kosztów za pracę w domu. Na przykład miesięczny dodatek uzgodniony ze związkami zawodowymi w administracji publicznej w krajach europejskich wynosi 15 EUR za każdy miesiąc [Di Nicola, 2017]. 
Wśród wad telepracy, które odnieść można do pracowników, najczęściej wymienia się m.in. narastające poczucie społecznej izolacji, jakie wytwarza się poprzez ciągłe korzystanie $\mathrm{z}$ sieci internetowej i zastępowanie nią bezpośrednich relacji ze współpracownikami. Ponadto w literaturze przedmiotu podkreśla się również, że telepraca może prowadzić do pracoholizmu poprzez destabilizację życia telepracownika wynikającą z elastyczności wykonywanych czynności zawodowych.

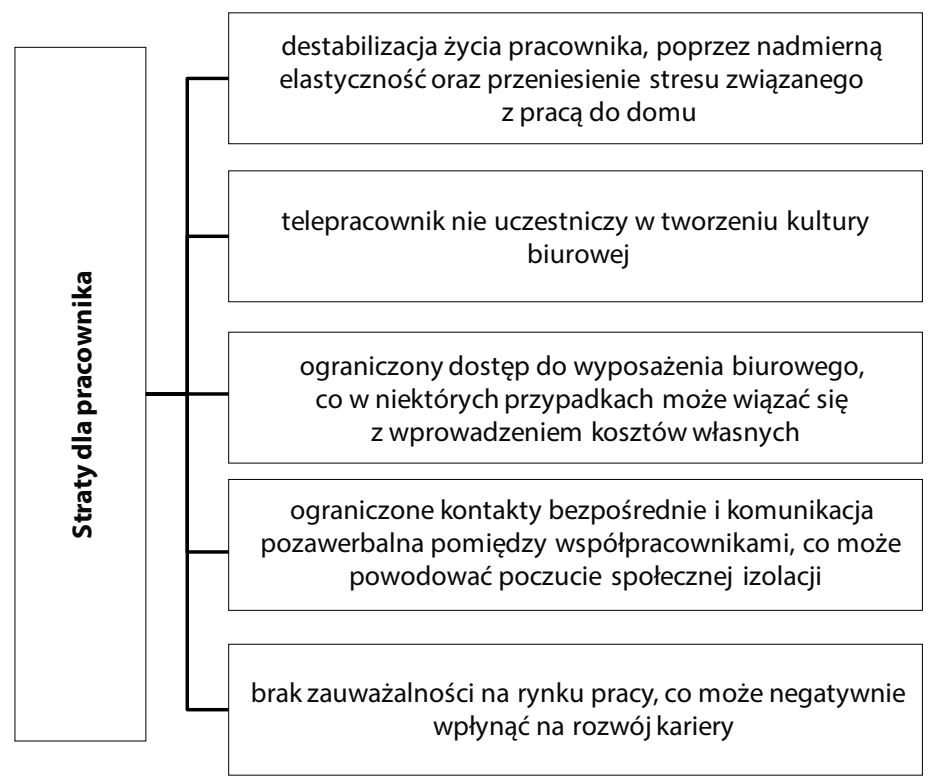

Schemat 4. Straty, które ponosi pracownik podejmujący pracę w społecznej przestrzeni Internetu

Źródło: opracowanie własne na podstawie: Makowiec, 2016: 63-64.

Zdarza się również tak, że pracownicy, rozpoczynając pracę za pośrednictwem sieci internetowej, ponoszą indywidualne koszty w związku z ograniczonym dostępem do wyposażenia biurowego. Istotnym elementem, uważanym również za barierę związaną z zapośredniczeniem pracy zawodowej przez sieć, jest utrata możliwości nawiązywania kontaktów z osobami z pracy, co może spowolnić rozwój kariery zawodowej pracownika. Ponadto dzielenie przestrzeni domowej z zawodową może również nieść ze sobą pejoratywne konsekwencje dla jednostki pracującej przez sieć WWW.

Nie należy zapominać jednak, że telepraca niesie wiele korzyści dla pracownika (zob. schemat 5), przede wszystkim zwiększa elastyczność i niezależność w wykonywaniu czynności zawodowych. 


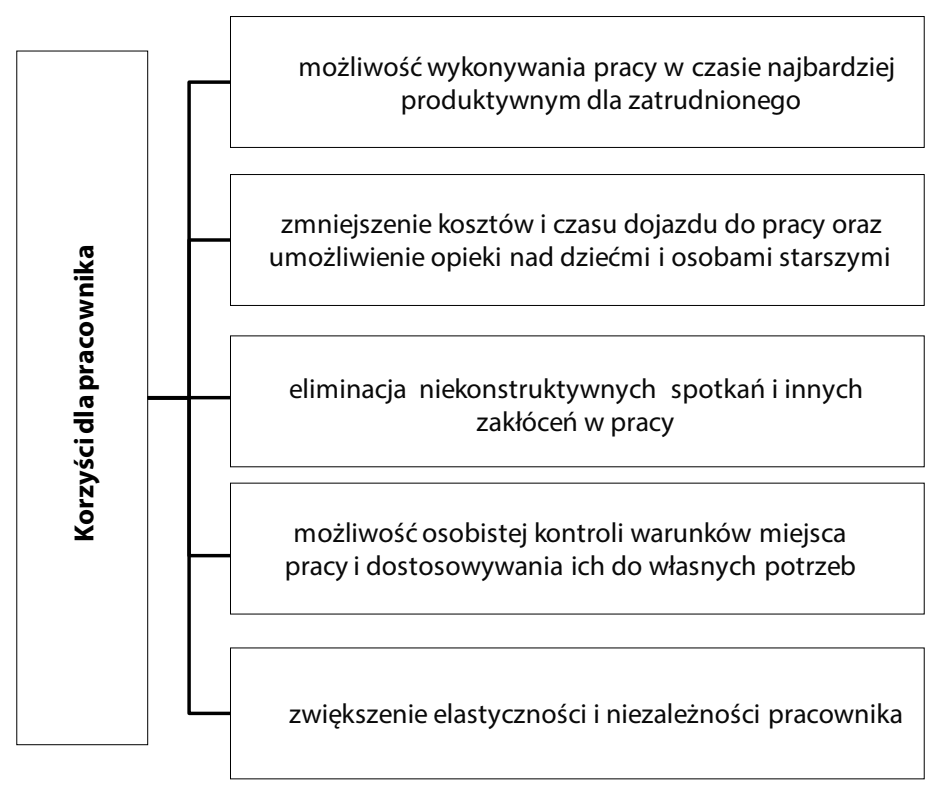

Schemat 5. Korzyści, które zyskuje pracownik podejmujący pracę w społecznej przestrzeni Internetu

Źródło: opracowanie własne na podstawie: Makowiec, 2016: 63-64.

Telepraca pozwala również na intensywny rozwój pracowników np.: poprzez możliwość uczestnictwa w wielu zespołach projektowych jednocześnie, przy czym przestrzeń geograficzna nie stanowi już żadnej bariery. Możliwość wykonywania pracy przy użyciu Internetu ma jeszcze jeden istotny dla pracownika plus, a mianowicie niemal całkowicie eliminuje niekonstruktywne spotkania i inne zakłócenia pracy, których pracownicy tradycyjni doświadczają na co dzień.

Warto nadmienić, że całościowy bilans zysków i strat związany z przeniesieniem działań pracowniczych do sieci powinien wiązać się z możliwościami organizacji, w której taka forma pracy jest wdrażana. Jak wskazuje Francesca Brumm, pracownicy korzystający z możliwości telepracy przedstawiają wyższy poziom zaangażowania organizacyjnego oraz wykazują chęć eksperymentowania z harmonogramami zadaniowymi, aby znaleźć równowagę pomiędzy pracą a życiem osobistym. Dlatego pracodawca powinien jednocześnie promować elastyczność w wykonywaniu czynności zawodowych, jednak z dostosowaniem do zasad i możliwości organizacji, w której zatrudniani są pracownicy [Brumm, 2016: 12].

Należy podkreślić, że przedstawione wady i zalety telepracy z punktu widzenia pracownika i pracodawcy wynikają przede wszystkie $\mathrm{z}$ charakteru i rodzaju zlecanych i wykonywanych czynności zawodowych. Nie zmienia to jednak faktu, że rola e-pracy w każdym segmencie rynku pracy odgrywa coraz to istotniejsze znaczenie, a w niektórych dziedzinach wręcz kluczowe. 


\section{Zakończenie}

W wyniku ukonstytuowania się sieciowej przestrzeni produkcji zmianie uległ nie tylko sposób wykonywania pracy, lecz także jej znaczenie, zarówno dla pracodawcy, pracownika, jak i otoczenia społecznego, wokół którego praca jest nadbudowana. Nastąpiła ekspansja narzędzi sieciowych zmieniających sposób wykonywania czynności zawodowych.

Telepraca jako forma elastycznej organizacji pracy zawodowej spopularyzowana została pod koniec lat dziewięćdziesiątych XX wieku, kiedy to korzystanie z komputerów, laptopów, telefonów komórkowych i wyrafinowanego oprogramowania telekomunikacyjnego stało się codziennym wymogiem pracy. Taki stan rzeczy niósł ze sobą szereg pozytywnych i negatywnych konsekwencji dla pracowników, którzy realizowali swoje czynności zawodowe za pośrednictwem społecznej przestrzeni Internetu.

Główną cechą charakterystyczną przeniesienia pracy zawodowej do społecznej przestrzeni Internetu jest jej duża elastyczność połączona z deregulacją czasu trwania, co może być interpretowane zarówno jako zaleta, jak i wada $\mathrm{z}$ punktu widzenia pracodawcy i pracownika. Pomimo ograniczeń i barier wynikających z telepracy społeczna przestrzeń Internetu oferuje wiele możliwości rozwoju. Wciąż ulepszanie nowych narzędzi służących do poprawienia wydajności przestrzeni produkcji w sieci może z czasem doprowadzić do zminimalizowania strat związanych z wykonywaniem pracy przy użyciu Internetu.

Pracownicy wydają się skłonni do wyboru tej formy pracy, ponieważ poprawia ona ich życie zawodowe i społeczne, zmniejsza ograniczenia w pracy, a oni uzyskują autonomię. Telepraca stała się odpowiedzią dla ludzi na różnych etapach życia, gdy uczą się lub wychowują dzieci. Telepracownik może dzięki niej dopasować swoje indywidualne preferencje do czynności zawodowych, poprzez zdecydowanie kiedy i gdzie pracować.

\section{Bibliografia}

Brumm F. (2016), Telework Is Work: Navigating the New Normal, „Cornell HR Review”, $5(10)$.

Di Nicola P. (2017), Smart Working and Teleworking: Two Possible Approaches to Lean Organisation Management, Istituto Nazionale di Statistica, Roma.

Duchna S., Paluszkiewicz M. (2013), Podporządkowanie telepracownika w stosunku pracy, „Zeszyty Prawnicze”, 13(1).

Eurofound (2017), Work-life Balance and Flexible Working Arrangements in the European Union, Dublin.

Kamerschen D., Mc Kenzie R., Nardinelli C. (1992), Ekonomia, tłum. D. Filar, K. Pawlikowska, Fundacja Gospodarcza NSZZ ,Solidarność”, Gdańsk.

Książek D. (2004), Telepraca, „Praca i Zabezpieczenie Społeczne”, 7(4). 
Makowiec M. (2016), Metodyka humanizowania telepracy, Wydawnictwo Uniwersytetu Ekonomicznego, Kraków.

Malcolm W., Morgen W. (2005), Zarządzanie organizacją wirtualną, Oficyna Ekonomiczna, Kraków.

Marciszewski E. (1983), Zarys socjologii pracy, Wydawnictwo WSP, Bydgoszcz.

Nilles J.M. (2003), Telepraca. Strategie kierowania wirtualna zatoga, tłum. A. Ehrlich, Wydawnictwa Naukowo-Techniczne, Warszawa.

Pilch T. (2003), Encyklopedia pedagogiczna XXI wieku, Wydawnictwo Naukowe PWN, Warszawa.

Spytek-Bandurska G. (2013), Telepraca $w$ Polsce - aspekty prawne i społeczne, „Problemy Polityki Społecznej. Studia i Dyskusje", 21(2).

Szewczuk W. (1998), Encyklopedia psychologii, Fundacja Innowacja, Warszawa.

Szpunar M. (2008), Przestrzeń Internetu - nowy wymiar przestrzeni społecznej, Wydawnictwo AGH, Kraków.

Tavares A.I. (2017), Telework and Health Effects Review, „International Journal of Healthcare", 3(2).

Zakrzewska-Szczepańska K. (2015), Bhp przy telepracy, „Praca i Zabezpieczenie Społeczne", 9(5). 